\title{
Transition towards Circular Economy in the Food System
}

\author{
Alexandra Jurgilevich ${ }^{1, *}$, Traci Birge ${ }^{2,+}$, Johanna Kentala-Lehtonen ${ }^{3,+}$, \\ Kaisa Korhonen-Kurki ${ }^{1,+}$, Janna Pietikäinen ${ }^{1,+}$, Laura Saikku ${ }^{4,+}$ and Hanna Schösler ${ }^{5,+}$
}

Received: 9 October 2015; Accepted: 7 January 2016; Published: 12 January 2016

Academic Editor: Helmut Haberl

1 Department of Environmental Sciences/Helsinki University Centre for Environment, University of Helsinki, Viikinkaari 2A, P.O. Box 65, Helsinki 00014, Finland; kaisa.korhonen@helsinki.fi (K.K.-K.); janna.pietikainen@helsinki.fi (J.P.)

2 Department of Agricultural Sciences, University of Helsinki, P.O. Box 27, Latokartanonkaari 5, Helsinki 00014, Finland; traci.birge@helsinki.fi

3 Forum for Environmental Information/Helsinki University Centre for Environment, University of Helsinki, Viikinkaari 2A, 2029, P.O. Box 65, Helsinki 00014, Finland;

johanna.kentala-lehtonen@ymparistotiedonfoorumi.fi

4 Finnish Environment Institute (SYKE), Mechelininkatu 34a, P.O. Box 140, Helsinki 00260, Finland; laura.saikku@ymparisto.fi

5 Research Division of Food and Health Sciences, University of Bayreuth, Universitätsstraße 30, Bayreuth 95440, Germany; hanna.schoesler@uni-bayreuth.de

* Correspondance: Alexandra.jurgilevich@helsinki.fi; Tel.: +358-451-87-6070

+ These authors contributed equally to this work.

\begin{abstract}
Growing population and increased demand for food, inefficient resource use and food distribution, environmental impacts, and high rates of food wasted at all stages of the food system are all calling for transition towards more sustainable practices. In this article we apply the concept of circular economy to the case of a sustainable food system. Furthermore, we explore the transition towards a circular food system through the lens of socio-technical transition theory towards sustainability. We discuss challenges and potential solutions for the production stage (focusing on nutrient flow), the consumption stage (focusing on meat consumption), and food waste and surplus management and prevention.
\end{abstract}

Keywords: circular economy; sustainability; food system; socio-technical transition

\section{Introduction}

Our current food production and consumption habits are unsustainable. Food production generates various environmental impacts, such as eutrophication and increased $\mathrm{CO}_{2}$ emissions [1-3]. As per different estimates, approximately $30 \%-50 \%$ of food intended for human consumption is wasted at different stages of the food system $[4,5]$. Current inefficiency in the food economy means we lose productivity, energy, and natural resources, and also bear the costs of throwing food away. More pollution and greenhouse gases are also created as a result of these processes. According to the UN's Food and Agriculture Organization [5], the inefficiencies of the food economy cost, globally, as much as a trillion dollars a year, or even two trillion dollars when social and environmental costs are included. Circular economy offers tools to enhance and optimize for sustainability within the Western food system. 
Circular economy uses theory and principles from industrial ecology. The aims of industrial ecology are to close the loop of materials and substances, and reduce both resource consumption and discharges into the environment. Industrial metabolism in industrial ecology refers particularly to the idea of industrial systems working as natural ecosystems [6]. Circular economy is an industrial economy that is restorative by design and mirrors nature in actively enhancing and optimizing the systems. It applies several principles from nature: production out of waste, resilience through diversity, the use of renewable energy sources, systems thinking, and cascading flows of materials and energy [7]. Circular economy means reuse, repair, refurbishing, and recycling of the existing materials and products; what was earlier considered to be waste becomes a resource. Our current economic system uses the linear economic model "take-produce-consume-discard", which assumes that economic growth can be based on the abundance of resources and unlimited waste disposal. Circular economy regarding the food system implies reducing the amount of waste generated in the food system, re-use of food, utilization of by-products and food waste, nutrient recycling, and changes in diet toward more diverse and more efficient food patterns. Avoidance of food waste and surplus is also a consumption issue related to consumer food competences and skills. The loop of nutrients related to the food system can, principally, be closed. The loop of matter can be partly closed relating to the reuse of food, and the utilization of byproducts and waste. Minimization of food surplus and waste reduces the overall matter consumption in the economy, thus decreasing the flow of matter related to the linear economy. The measures must be implemented both at the producer and consumer levels and, finally, in waste management. In the transition towards sustainability [8], interestingly, small-scale experiments offer opportunities for local, and also national, policy development.

Despite the increasing interest around the concept of circular economy, there are currently few number of studies on the concept as such [7,9]. The aim of this paper is to shed light on the concept of circular economy in the context of a circular food system. Potential solutions and policy recommendations analyzed through a lens of transition theory are presented in order to assist the transition towards a circular food system with experiments offered by circular economy into mainstream practice. In this paper, a circular food system includes three interconnected stages, and refers to the implementation of principles of circular economy presented above (Figure 1). Figure 1 serves as the framework for this paper. Whereas it does not represent the whole food system and flows within it, it shows the three stages at which principles of circular economy regarding food system can be implemented. The flows represented by the arrows refer to nutrient and matter flows. Not all nutrients and matter can be cycled; however, there is potential to increase the volume of circulating nutrients and matter, decrease the intake of new nutrients and matter, and close the loops partially. Each of the stages has niche modes for experiments that provide solutions for socio-technical transition to a circular economy in food systems. We give examples of experiments that have emerged in local level platforms or protected spaces here called "niches". Each of these stages is presented in the context of circular economy in a sustainable food system as brought up in HENVI Science Day. 


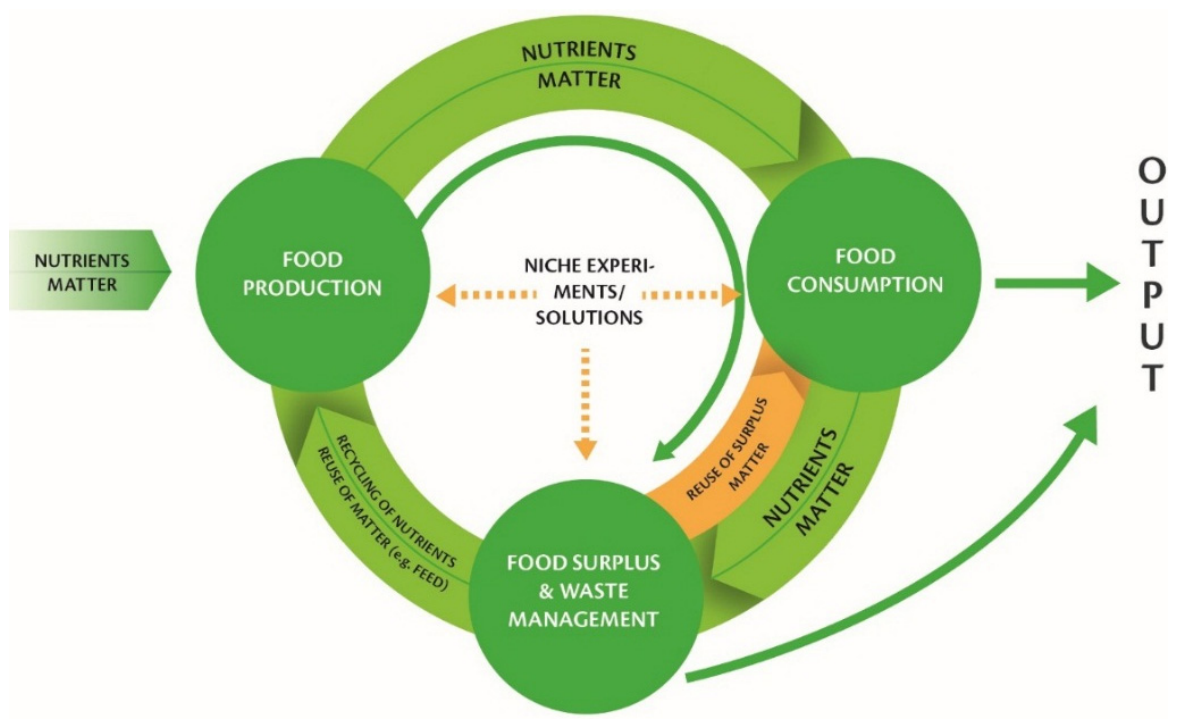

Figure 1. Three stages of the food system in a circular economy. Circular economy regarding the food system implies reducing the amount of waste generated in the food system, reuse of food, utilization of byproducts and food waste, and nutrient recycling. The measures must be implemented both at the producer and consumer levels, and finally in the food waste and surplus management.

In this paper, food production focuses on nutrient cycling where producers play a large role. Food consumption is related to the efficiency of food consumption. Food waste and surplus management refers to utilization of by-products and food waste in the production phase and to reuse of food and surplus avoidance in the consumption stage, mainly based on consumer competence and skill. Figure 1 illustrates that food waste and surplus are generated both in the production and consumption stage.

The paper highlights the key issues and findings brought up in HENVI Science Day titled "Towards Circular Economy-Designing a Sustainable Food Cycle" that took place on 21 April 2015 in Helsinki, Finland. Moderated, recorded roundtable discussions were central to the HENVI Science Day and participants included scientists, researchers, and representatives from private and public sectors and NGOs. The findings in this commentary paper are based on the recorded discussions and presentations in the event. This paper is intended to stimulate thought and it is hoped that the presented findings can be used in further research and analyses on circular economy and circular food systems. Potential solutions and policy recommendations are presented in order to assist the transition of experiments offered by circular economy into mainstream practice for promoting more sustainable food systems.

We start with shortly presenting transition theory and how it is applied here. Secondly, we highlight the key ideas brought up in the HENVI Science Day grouped under the three stages of the food system. Due to the background of the participants in the event, the discussed policy context is EU-oriented and practical examples mostly represent the Finnish situation. However, global interdependence of flows and activities in the food system is taken into account. As brought up in the HENVI Science Day, we consider potential solutions for each of the stages of the food system and give examples of experiments that have emerged. Finally we present some thoughts on how to achieve a transition towards circular economy in the food system. 


\section{Theory of Socio-Technical Transitions to Sustainability}

Socio-technical transitions are long-term and fundamental transformation processes through which established socio-technical systems shift to more sustainable modes of production and consumption [10]. These processes engender change in infrastructures and technologies, as well as citizens' competencies, practices, and world views [11,12]. Careful analysis of practical examples and experiments offers a good foundation for designing and adapting policy frameworks on the basis of barriers and opportunities identified. Experimentation does not mean neglecting policies; rather, it recognizes the need for providing space for the transition to be developed from both the bottom-up and top-down, simultaneously.

New approaches are rarely viable as such when they emerge. Geels and Schot (p. 400, [8]) present a multilevel perspective to sustainability transition where "niches" form a local level platform: "Technological niches form the micro-level where radical novelties emerge. These novelties are initially unstable socio-technical configurations with low performance". Experiments (novelties) are carried out and developed at the niche level by small networks of dedicated actors, often outsiders. Such experiments aim to create something new and concrete that is restricted in terms of time, space, scope, and actors, but that has the potential of having wider societal relevance through various up-scaling mechanisms [13]. These local niches can serve as protective spaces for new solutions to evolve: for the developers to find sensible and user-friendly ways of providing services, for users to learn to use them and adapt them to their everyday life, and for regulators to learn how to govern them $[14,15]$. The theory of multilevel socio-technical transitions has been successfully applied to many cases but it has also received some criticism regarding delineation, possibilities of cross-fertilization between regimes, and characteristics of niches to serve as a platform for continuous development of the novel technology, not only for emergence of novelties [16].

Experiments offer opportunities for many kinds of learning and competence development: technological, social and institutional. However, learning and upscaling from experiments requires dedicated work and systematic transfer of lessons learned [17,18]. Experimentation is triggered by an intentional destabilization of existing institutions and routines in that actors are seeking to explore novel possibilities and outcomes of informed deliberation. Careful analysis of practical examples and experiments offer a good basis to design and adapt policy frameworks on the basis of barriers and opportunities recognized.

Berkhout et al. [19] have criticized transition theory for its emphasis on bottom-up approaches at the cost of top-down activities. While experiments and niches are of high importance in the process of transition, there is no less urgency in transitioning of the whole system towards greater sustainability. It must be noted that not all emerging experiments are viable or prove to be sustainable. However, they indicate the beginning changes at niche levels. In this paper we apply transition theory in analyzing possibilities for a transition towards circular economy regarding the food system. While focusing on the changes that can be upscaled from the niche level, we also highlight that the change should also come from the mainstream level.

\section{Problems at Different Stages in the Food System}

We focus on three stages of the food system regarding circular economy: food production, food consumption, and food waste and surplus management (Figure 1).

\subsection{Food Production}

The growing population, especially the increasing proportion of the middle class, leads to increasing demand for nutrients needed for food production. Demand for nutrients, especially phosphorus $(\mathrm{P})$, is growing drastically faster than the human population due to a shift to meat-based diets, which require far more $P$ than plant-based diets [1]. The main driver of sustainable $P$ use has been water pollution concerns. However, the scarcity of phosphate rock, which is a non-renewable 
resource, is increasingly putting pressure on developing methods and policies for the recovery and reuse of $P$ from multiple sources in the human system e.g., human and animal excreta and food and crop waste $[20,21]$. In addition to the recovery and reuse of $P$ as recycled fertilizer, also increased efficiency of $\mathrm{P}$ use in agriculture will be a key to ensure food security [22]. It is estimated that $21 \%$ of $\mathrm{P}$ fertilizer input into arable soil is eventually ingested by humans and $57 \%$ is lost to inland and coastal waters (p. 297, [23]). The European Union (EU) has listed P as a critical raw material [24].

In addition to vast nutrient losses, there is an increasing nutrient imbalance throughout the globe. Rich countries accumulate nutrients in their arable soil while poor countries do not have equal access to nutrients and their soil suffers from severe P deficit and accordingly low agricultural production [25]. Meat production is one of the most nutrient-intensive agricultural sectors. Thus, industrialized livestock production and trade create a vast virtual trade in nutrients, land, and water, which are used at the production site but not embedded in the product, as e.g., Japan's intensive chicken and pig meat import imply that half of Japan's virtual nitrogen total is lost in the US [26].

This nutrient imbalance is also exacerbated by structural development of industrialized agriculture in which animal and plant production are concentrated in separate areas. Across Europe and other areas with high concentrations of livestock, agricultural structural development results in excess manure in places where soils are already saturated with nutrients $[27,28]$.

\subsection{Food Consumption}

One of the critical issues in food consumption is the excessively high ratio of industrially-produced meat in the Western diet. Next to health issues associated with consumption, such production systems are a heavy burden on the environment due to high nutrient and energy demands, greenhouse gas emissions and other pollutants. For instance, the embodied phosphorus of meat products is estimated to be three times higher than that of vegetal products [29].

However, it is not easy for a consumer in a modern world to make more sustainable choices. On the one hand, the trend towards rationalization and convenience has enabled consumers to make choices on a routine level without sparing much thought. Therefore, many consumers are not aware of the entire food chain, the various actors involved, and the moral implications associated with their decisions. The setting in which people currently make their routine food choices is not conducive to more sustainable consumption patterns.

Moreover, food consumption patterns are linked with people's value orientations, emotions, personal and collective identity, traditions, and food culture. The consumption of meat is, for example, bound to particular framings of masculinity and is also linked to ethnicity [30]. Many people also feel that dietary choices are a private matter, and that their freedom of choice living in a pluralistic society would be impinged upon by governmental dietary recommendations. This makes it extremely challenging to instigate desired changes on a systems level.

\subsection{Food Waste and Surplus Management}

Food surplus is edible, discarded food that is abandoned intentionally, has been removed from sale from e.g., a grocery store, or otherwise fails to be consumed due to various reasons. Food surplus becomes food waste when it becomes inedible. Food waste is unnecessary waste, which could have been avoided if the food was prepared or preserved, or if inedible waste was otherwise utilized. Food waste occurs at all stages of the food supply chain, from the initial farming stage, through manufacturing/processing, to retail and consumption. In low-income countries, most losses occur during primary stages of production but high-income countries frequently waste over $40 \%$ at the consumption stage [5]. 
The estimates of food waste differ throughout literature depending on the definitions and what is counted. Lundqvist et al. [31] estimate that as much as half of the food is wasted before and after it reaches the consumer. According to Stuart [4] approximately $30 \%-50 \%$ of edible material intended for human consumption (including animal material that is intentionally fed to animals or is discarded as byproducts), is wasted in North America and the EU at different stages of the food supply. FAO report states that $30 \%$ of edible food produced for human consumption gets lost or wasted globally throughout the whole supply chain [5]. Even considering the lowest estimates, the losses are still vast. They occur for various reasons at different stages, and are distributed differently between the developing and developed countries [31]. Overall, food wastage is higher in developed countries than in the developing. In the developing countries food losses and waste occur mainly in the production stage due to technological reasons, such as poor harvesting procedures and technologies, poor storing conditions, and inefficient transportation and logistics. Whereas in developed countries up to $40 \%$ of losses occur at the consumption stage [5]. This paper focuses on the losses at the consumption stage (retailer and household level) due to such reasons as e.g., consumer behaviors, unsustainable diets, and food standards.

The food waste problem also has environmental implications. An example of impacts related to food waste disposal include the problem of landfilled food waste producing extra methane during decomposition. In addition to that, unclaimed or surplus food waste has embedded greenhouse gas emissions that arise during the whole food supply chain, from production to processing, transportation, storing, distribution and retail [32].

\section{Potential Solutions for Transition at Different Stages in the Food System}

Circular economy offers solutions in moving towards a sustainable food system. Potential solutions are discussed for food production, consumption, and waste management. The circular economy aims at using materials first as products, then as re-used/recycled materials and, finally, as energy. It aims to close the loops at the smallest possible cycles and use a minimal amount of auxiliary inputs, such as energy, in the process.

For sustainability transition, both infrastructures and technologies, as well as citizens' competencies, practices, and world views, need to change [11,12]. The potential solutions identified in this paper related to nutrient cycling include recovering nutrients from manure, recovering and reusing nutrients in sewage sludge, cascading use of materials, as well as supporting local farms and de-specialized agricultural holds (Table 1). Solutions related to citizens and consumers often take the role of experiments and include community supported agriculture, different strategies towards shifting to a more plant-based diet, and education on food waste minimization. These policies also contribute to better food waste and surplus management. In addition, various institutional barriers can be re-envisioned to reduce food waste and surplus (e.g., food quotas and standards, redistribution of unclaimed food). 
Table 1. Summarized potential solutions and policies suggested during the HENVI Science day.

\begin{tabular}{|c|c|c|}
\hline $\begin{array}{c}\text { Food System } \\
\text { Stage }\end{array}$ & Policies and Solutions & Examples of Experiments \\
\hline $\begin{array}{l}\text { Food } \\
\text { production }\end{array}$ & $\begin{array}{l}\text { - Support local farming through various policy tools (investment } \\
\text { support, tax incentives for nutrient recovery and subsequent } \\
\text { re-use, improve opportunities to sell local foods locally) } \\
\text { - } \\
\text { Support the use of recovered and recycled nutrients as a partial } \\
\text { substitution for imported nutrients to tackle nutrient imbalance } \\
\text { - } \quad \text { Use holistic approach for nutrient flow regulation: coordinated } \\
\text { and comprehensive policy packages to regulate nutrient flows, } \\
\text { close the loops and prevent leakages; demand "origin passports" } \\
\text { for nutrients (phosphorus) to verify sustainable sources and } \\
\text { encourage recovery rather than importing } \\
\text { - Consider all stakeholders and users involved while creating } \\
\text { nutrient regulation } \\
\text { Support local producers who "de-specialize" or already practice } \\
\text { mixed farming, i.e., have both animal and plant production and } \\
\text { use manure for nutrients or support larger-scale infrastructures, } \\
\text { where recycling of nutrients from manure and waste to field is } \\
\text { organized in a holistic way }\end{array}$ & $\begin{array}{l}\text { Manure. Recovery of nutrients from manure helps to avoid } \\
\text { losses, contributes to resource savings, and provides resilience to } \\
\text { agricultural producers. Treatment of manure calls for new } \\
\text { technological innovations to overcome the problem of nutrient } \\
\text { imbalance both globally and locally. } \\
\text { Sewage sludge. Humans excrete almost all ingested P. } \\
\text { In communities utilizing wastewater treatment, P is trapped at } \\
\text { waste water treatment plants. At these P hot spots P can thus be } \\
\text { recovered and re-used, which would contribute to } \\
\text { resource-efficiency, energy-efficiency and resilience. } \\
\text { Smart agriculture and local food movement. A renewed interest in } \\
\text { direct sale from farmers to customers with various new } \\
\text { innovations is increasing. Community Supported Agriculture, } \\
\text { food circle buying clubs, seasonal food box subscriptions, on-line } \\
\text { farm shops are ongoing experiments. Benefits include reduced } \\
\text { packaging, improved product freshness and transparency, } \\
\text { shorter supply chains, and developing relationships between } \\
\text { farmers and consumers. }\end{array}$ \\
\hline $\begin{array}{l}\text { Food } \\
\text { consumption }\end{array}$ & 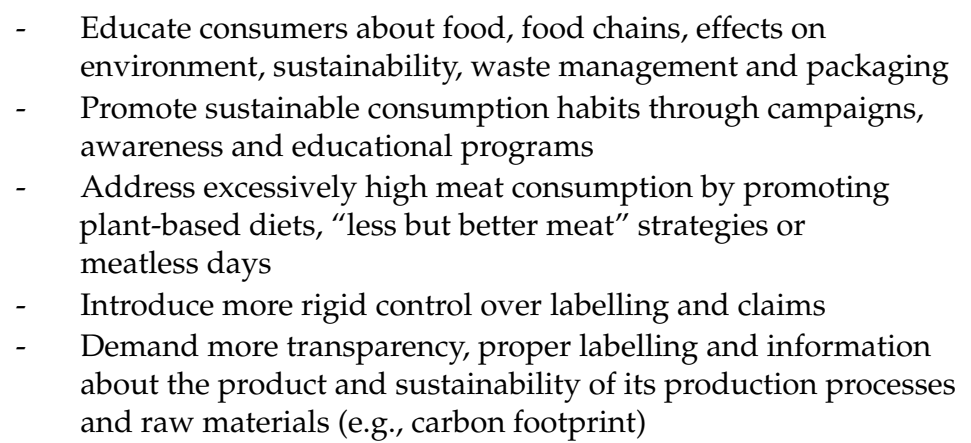 & $\begin{array}{l}\text { - Vegetarian day is an established practice in Helsinki's schools: } \\
\text { once a week only vegetarian school meal is offered to students. } \\
\text { "Less but better meat" is a strategy that promotes consuming } \\
\text { smaller portions of meat obtained from extensive production, } \\
\text { such as organic or free-range. } \\
\text { "Dumpster diving" is a radical experiment where mainly young } \\
\text { people collect free food that has been thrown out by } \\
\text { supermarkets. but is still edible }\end{array}$ \\
\hline
\end{tabular}


Table 1. Cont.

\begin{tabular}{|c|c|c|}
\hline $\begin{array}{l}\text { Food System } \\
\text { Stage }\end{array}$ & Policies and Solutions & Examples of Experiments \\
\hline $\begin{array}{l}\text { Food waste } \\
\text { and surplus } \\
\text { management }\end{array}$ & $\begin{array}{l}\text { - Promote sustainable food production and consumption practices } \\
\text { - } \quad \text { Close material loops at every stage possible } \\
\text { - } \quad \text { Support local energy production using manure from farms as } \\
\text { local energy source or composting of bio-waste to produce } \\
\text { gas locally } \\
\text { - } \quad \text { Revise food standards ("ugly" food is not waste!) } \\
\text { - } \quad \text { Revise possible market distorting quotas and subsidies } \\
\text { - } \quad \text { Support businesses which apply such practices as industrial } \\
\text { symbiosis, re-furbishing, re-manufacturing, work in cascades, etc. } \\
\text { (through tax incentives or other economic instruments) } \\
\text { Remove legal barriers at the institutional level in order to ease } \\
\text { the redistribution of unclaimed food } \\
\text { - Support consumers' sustainable choices in packaging, } \\
\text { deposit-and-refund schemes and recycling } \\
\text { Regulate packaging in a way that balances rules of packaging, } \\
\text { prolonged shelf-life and health issues }\end{array}$ & $\begin{array}{l}\text { - Cascades - creating added value from material considered as } \\
\text { waste (e.g., coffee growing: berry is consumed by people, } \\
\text { the remaining can be used for growing mushrooms that can be } \\
\text { sold as food, the left over can be fed to animals and mushroom } \\
\text { roots can be used to create mycelium packaging. Animals } \\
\text { produce manure and bacteria, which can be used to } \\
\text { produce biogas). } \\
\text { Biogas production and deriving nutrients from food waste. } \\
\text { - Ban for supermarkets on throwing away food waste (e.g., recent ban } \\
\text { in France where supermarkets are obliged to pass food waste } \\
\text { onto charities instead of dumping). }\end{array}$ \\
\hline At all levels & $\begin{array}{l}\text { Support the development of local experiments into mainstream } \\
\text { practices at all stages of food supply chain }\end{array}$ & \\
\hline
\end{tabular}




\subsection{Food Production}

Since nutrient flows impact multiple users and sectors, regulation of nutrient flows should be conducted using a cross-sectoral approach. Circular nutrient use in the food sector includes the following processes and actors: in the agricultural sector the farmers are the nutrient-users; in the waste sector wastewater treatment plants concentrate and recover nutrients; in the energy sector biogas plants produce energy and recycled nutrients; in the food markets the consumers are the final users of foods; and in urban planning the sanitation and waste systems determine how nutrients can be managed in the society safely.

As regulating nutrient flows is complex and multi-tiered, a need to create a coordinated and comprehensive policy package at the EU level exists. This should take into account both the whole nutrient flow, as well as policies for all crucial nutrients ( $\mathrm{P}$ in particular). A sustainable regulation would consider the problem of nutrient imbalance between different countries. Solutions for this could be e.g., introduction of raw material origin passports and certificates of extraction and sustainable management that would indicate the sustainable source of the substance (e.g., P). The raw material passport could be e.g., a label informing the consumer about the origin of fertilizer-P in the food product, thus enabling consumers to choose products with recycled P. This is in accordance with Schröder et al. [22], who demonstrate a need for new policies to ensure that all $\mathrm{P}$ exported from agricultural farms should be compensated by P recovery from waste streams instead of using P mined from phosphate rock. More focus and incentive should also be given to nutrient recovery and recycling practices and technologies, which should be encouraged as a partial substitution for the import of nutrients. An integrated system framework will allow us to identify the overall flow of $P$ through the ecological and human systems and help to identify the hotspots, where efficiency and reuse of $P$ can be improved and how this should be reflected in the development of technologies and policies on different scales and in various sectors [33,34].

Pagotto et al. [35] note in their analysis of resource potential and efficiency in the Australian agri-food sector that the inherent complexity of increasing cross-sectoral efficiency and recycling requires sound policies and an environmental-oriented approach, as well as stakeholder engagement in all sectors of the supply chain. Localized food systems are one area of interest within the circular economy. Food miles and supply chain length, as well as food quality, equity, and security are at the forefront of efforts for promoting local foods systems. Strengthening of local food systems is seen as a way to increase sustainability of food systems [36], and the European Union [37] and individual countries (e.g., Finland) are implementing local food strategies. Localized food systems have strong potential for increased environmental sustainability through nutrient cycling and waste reduction. For example, combining local and seasonal elements in short-supply chains ("local foods") reduces storage and transportation while providing better demand-supply balance, which contributes to food waste prevention [37]. Sustainability and food security are enhanced in localized food systems through specializing in regional products, and European studies have noted that consumers place a higher value on food purchased in local markets, which in turn has a positive impact on consumer wastage [37]. Tracking and transparency benefits from a shorter production chain, and this may contribute to food safety and accountability.

While local foods initiatives provide interesting examples of experiments in circular food economy, it is important to remember that the sustainability of any food system is contextual and dependent upon ecologically sound farming practices [37,38].

Additionally, localized farming networks should be supported through various tools as they help tackle the issue of increasing nutrient imbalance, provided that nutrient recovery and recycling practices are taking places as a substitute (at least partial) to import.

\subsection{Food Consumption}

The theory of socio-technical transitions contributes to our understanding of changing food consumption patterns, because it focuses on the need of a bottom-up transition rather than 
superimposed changes. Experiments that evolve within a particular society will be in line with the socio-cultural background and are more likely to have the potential to become mainstream. Additionally, the emphasis on learning and competence development is an important contribution of this theory, as research shows that the shift toward a less meat-centered diet necessitates a new set of competences in preparing healthy meat-free meals [30].

Thus, consumers play an important role in the transition towards circular economy through making more sustainable choices and promoting them further. They need to support sustainable policies, and sustainable experiments, which will result in upscaling of some of the initiatives. Pace of the transition is influenced by private consumers, as well as larger actors, such as the hospitality industry and municipal or state services (schools, hospitals, care homes).

Certainly, awareness campaigns will contribute, but they are not enough to reach out to the entire population. Additionally, regarding the individual consumer, it is necessary to address the "food environment" that people live in. To this end, supermarkets, food service, and public catering need to be involved in efforts to increase amounts and attractiveness of plant-based foods and to decrease, for example, portion size of meat being served. Studies show that different consumer groups can be targeted with policy efforts promoting "meatless days" and those strategies promoting "less but better" meat [39]. A promising example of policy efforts to promote healthy and more environmentally friendly eating patterns is the "Nordic diet". The idea was to translate health-promoting dietary recommendations into practical recommendations tailored to regional circumstances, which may help to preserve cultural diversity, is locally oriented, and culturally appropriate [40]. Instead of industrially-produced meat from farmed animals, the Nordic diet emphasizes the consumption of native fish and other seafood, as well as wild and pasture-fed land-based animals [40]. Such models address food consumption patterns as a whole in the context of health and environment, while proposing food styles that people can identify with because they are regionally and culturally embedded. They are also suitable for communicating about food choices while being sensitive to gender and ethnicity [41].

In order to support consumers in making sustainable food choices it is also necessary to educate them on labelling and to create increased transparency regarding the degree to which these are controlled and trustworthy. However, studies have shown that it is mainly well-informed consumers who tend to make healthier and more sustainable decisions already that pay attention to labels and are influenced by information campaigns. Therefore, policy efforts should be increasingly directed at using levers that influence contextual factors and create an environment-above and beyond the level of individual products-that is conducive to making healthier and more sustainable food choices.

\subsection{Food Waste and Surplus Management}

The major measure for food surplus reduction is prevention, followed by the re-use of surplus food for human consumption for people affected by food poverty, through redistribution networks and food banks. Studies suggest reducing food surplus throughout the whole food supply chain as a prevention measure for food waste [32]. Regarding food waste, it is necessary to differentiate between avoidable and unavoidable food waste, as this determines the priorities and ways of management and prevention. In cases of avoidable food waste, the main measures are prevention, followed by treatment of generated waste through recycling into animal feed and composting [32].

Currently the policies addressing food waste are situated in the waste management arena. In order to move away from end-of-pipe solutions to a more holistic approach, the concept of sustainable consumption and production needs to be integrated across all the relevant sectors, such as agriculture, food processing, retail, and waste management. On the production side, technological advances have been successful in reducing food waste, especially in developed countries. Material flows need to be closed, and both the introduction of new material into the system, as well as the exclusion of circulating material as waste, needs to be minimized. For example, localized food networks contribute to this ideology by offering simpler and more easily controlled systems. Such systems are associated with 
sustainability, food security, and food safety. Collected organic waste can be composted and used in agriculture, or used for anaerobic digestion in biogas production.

The quality standards of food, e.g., sizes, colors and shapes of vegetables, fruits, and berries should be re-evaluated ("ugly" food is not bad food).

Similarly, quota limits and subsidies should be revised at least partially according to consumption volumes and with the aim to avoid creation of incentives that drive farmers to produce crops which (1) are not necessarily most-needed from the point of view of the food production system; (2) are not sustainable from the point of view of the land productivity in the long run; or (3) are more efficiently farmed in other places.

In retail, policies regarding food labelling (e.g., "best before" and "consume by" dates) need harmonization and clarification to prevent avoidable waste. Finally, food safety regulations should reconsider the balance between safeguarding public health and unnecessary food waste and, thus, remove barriers associated with legal liabilities during the redistribution of food surplus. Incentives are needed to encourage producers and retailers to redistribute unwanted/unclaimed food. In food processing, policies promoting industrial symbiosis can further reduce food waste. In households, more education and awareness is needed for people to utilize food going to waste.

It is also necessary to consider the obstacles when shaping solutions for food waste reduction and prevention. Such aspects can include infrastructure (e.g., waste water treatment center may not be designed for P recovery), geographical challenges (e.g., distance between the dairy farms and field crop farms which makes transporting manure to the field unsustainable through high $\mathrm{CO}_{2}$ emission), as well as institutional structures and regulations.

\subsection{Mainstreaming the Experiments}

Some circular economy solutions may well remain fads that are soon forgotten, or niches that become established in their small social circle but have little influence on the mainstream. Some, however, have potential to be upscaled to mainstream practices. Promising experiments and the potential ways in which they challenge or change the mainstream can be identified when they fulfill certain conditions. For example:

- Do niche modes of circular consumption manage to change consumers' expectations (e.g., creating an expectation that food is always traceable or that organic food should always be available, thus influencing mainstream business)?

- Do niche modes of circular consumption manage to attach to some established practices or institutions (e.g., "vegetarian day" in Helsinki school catering, or new rules for food donation)?

- Niche multiplication: can a practice spread over several different populations for different reasons (veganism, raw food consumption) creating critical mass and demand from mainstream service providers?

- Niche/mainstream adaptation? How are (perhaps radical) circularity principles adapted to mainstream practices at the retailer (e.g., surplus food donation) or consumer level?

- De-institutionalization and unlearning of established practices: how are old (linear economy) practices broken or gradually phased out?

Whereas it is difficult and ambiguous to measure how the experiments influence the whole system, it is still possible to look at some indicators. Such indicators could relate to closing the loops in food systems and measure the amount of food waste produced and the amount of waste re-used, the amount of nutrients wasted and amount of nutrients recovered for further use, etc.

\section{Conclusions}

HENVI Science Day covered key issues for developing agricultural production, food consumption, and food waste management towards a more circular economy. Our findings are in line with previous literature showing that, besides innovative technologies and food waste reduction, circular economy 
sustainability solutions include supporting local food supply chains with less waste, closing nutrient loops, pricing the true cost of resource consumption and losses in natural capital, and creating policy mechanisms to promote recovery and reduce loss of critical raw materials in particular [42].

Such insights by themselves are not novel; many of the proposals are in use already or the problems well recognized. However, circular economy provides a framework in which society can create cross-sectoral policy to support varied initiatives in different "parts of the circle" for the ultimate goal of breaking away from the linear and extractive model to a more sustainable mode of production and consumption. In our examples of $\mathrm{P}$, meat consumption, and production-supply-disposal chains, we illustrate the types of linkages that must be considered, and the gaps that must be closed, to achieve circular economy within the agriculture and food sectors. The theory of socio-technical transition offers insights on how certain experiments on the way to circular economy in the food system can be upscaled to established practices.

Acknowledgments: This paper is the result of recorded focus group discussions during the HENVI Science Day 2015 "Towards Circular Economy-Designing a Sustainable Food Cycle" (http://blogs.helsinki.fi/ henvisciencedays-2015/). We would like to acknowledge the contribution of the keynote speakers: Per Mickwitz, Finnish Environment Institute, Francesco Nicolli, University of Ferrara/CERIS, Eva Heiskanen, Consumer Society Research Centre, University of Helsinki, Hanna Schösler, University of Bayreuth, Effie Papargyropoulou, University of Leeds, UK/University of Technology, Malaysia. The group discussions were recorded and summarized by Jaana Korhonen, Miia Kuisma, Anna Kuokkanen, Noora Manninen, Jaakko Mäkelä, Minna Mäkelä, Hanna Mäkinen, Mirko Pavicic, Inka Reijonen, and Aleksei Shcherbinin, University of Helsinki. We would like to acknowledge Kaisa Matschoss and Petteri Repo, Consumer Society Research Centre, University of Helsinki, for their contributions to the HENVI Science Day. We would also like to thank two anonymous reviewers whose useful comments have significantly improved the paper.

Author Contributions: The lead author, Alexandra Jurgilevich, has been responsible for data processing, structuring and conceptualizing the manuscript as well as for the Section 3.3, Section 4.3, Section 4.4 and partially conclusions. Kaisa Korhonen-Kurki has written the Section 2 and contributed to conceptualizing the manuscript. Janna Pietikäinen has written Section 3.1 and co-written Section 4.1 as well as contributed to conceptualizing the manuscript. Johanna Kentala-Lehtonen has contributed to introduction, Sections 3.2 and 4.3 and to data processing. Laura Saikku has written the introduction and has contributed greatly to Section 3.1. Traci Birge has contributed to Section 3.1, has co-written Section 4.1 and the conclusions, and edited the manuscript for language. Hanna Schösler has written Sections 3.2 and 4.2 and has contributed to the introduction. Sections 2-4 of the paper are based on the materials from HENVI Science Day. All authors have commented on the entire manuscript and contributed to the revisions.

Conflicts of Interest: The authors declare no conflict of interest.

\section{References}

1. Baroni, L.; Cenci, L.; Tettamanti, M.; Berati, M. Evaluating the environmental impact of various dietary patterns combined with different food production systems. Eur. J. Clin. Nutr. 2006, 61, 279-286. [CrossRef] [PubMed]

2. Tilman, D.; Fargione, J.; Wolff, B.; D'Antonio, C.; Dobson, A.; Howarth, R.; Schindler, D.; Schlesinger, W.H.; Simberloff, D.; Swackhamer, D. Forecasting Agriculturally Driven Global Environmental Change. Sci. Mag. 2001, 292, 281-284. [CrossRef] [PubMed]

3. Bennett, E.M.; Carpenter, S.R.; Caraco, N.E. Human Impact on Erodable Phosphorus and Eutrophication: A Global Perspective. BioScience 2001, 51, 227-234. [CrossRef]

4. Stuart, T. Waste: Uncovering the Global Food Scandal; Penguin Books Limited: London, UK, 2009.

5. Gustavsson, J.; Cederberg, C.; Sonesson, U.; van Otterdijk, R.; Meybeck, A. Global Food Losses and Food Waste-Extent, Causes and Prevention; FAO: Rome, Italy, 2011.

6. Ayres, R.U. Industrial Metabolism. In Technology and Environment; Ausubel, J.H., Sladovich, H.E., Eds.; National Academy Press: Washington, DC, USA, 1989; pp. 29-43.

7. Ellen MacArthur Foundation. Towards the Circular Economy. Economic and business rationale for an accelerated transition. Available online: http://www.ellenmacarthurfoundation.org/assets/ downloads/publications/Ellen-MacArthur-Foundation-Towards-the-Circular-Economy-vol.1.pdf (accessed on 24 June 2015).

8. Geels, F.W.; Schot, J. Typology of sociotechnical transition pathways. Res. Policy 2007, 36, 399-417. [CrossRef]

9. Stahel, W.R. The Performance Economy, 2nd ed.; Palgrave MacMillan: London, UK, 2010. 
10. Geels, F.W.; Schot, J. The dynamics of transitions: A socio-technical perspective. In Transitions to Sustainable Development: New Directions in the Study of Long Term Transformative Change; Grin, J., Rotmans, J., Schot, J., Eds.; Routledge: New York, NY, USA, 2010; pp. 11-104.

11. Geels, F.W. The dynamics of transitions in socio-technical systems: A multi-level analysis of the transition pathway from horse-drawn carriages to automobiles (1860-1930). Technol. Anal. Strateg. 2005, 17, 445-476. [CrossRef]

12. Shove, E. Putting practice into policy: Reconfiguring questions of consumption and climate change. Contemp. Soc. Sci. 2014, 9, 415-429. [CrossRef]

13. Bulkeley, H.; Castán Broto, V. Government by experiment? Global cities and the governing of climate change. Trans. Inst. Br. Geogr. 2012, 38, 361-375. [CrossRef]

14. Geels, F.W. Technological Transitions and System Innovations: A Co-Evolutionary and Socio-Technical Analysis; Edward Elgar Publishing: Cheltenham, UK, 2005.

15. Smith, A. Translating sustainabilities between green niches and socio-technical regimes. Technol. Anal. Strateg. Manag. 2007, 19, 427-450. [CrossRef]

16. Genus, A.; Coles, A. Rethinking the multi-level perspective of technological transitions. Res. Policy 2008, 37, 1436-1445. [CrossRef]

17. Raven, R.; Verbong, G. Multi-regime interactions in the Dutch energy sector: the case of combined heat and power technologies in the Netherlands (1970-2000). Technol. Anal. Strateg. 2007, 19, 491-507. [CrossRef]

18. Heiskanen, E.; Nissilä, H.; Lovio, R. Demonstration buildings as protected spaces for clean energy solutions-The case of solar building integration in Finland. J. Clean. Prod. 2015, 109, 361-375. [CrossRef]

19. Berkhout, F.; Smith, A.; Stirling, A. Socio-technological regimes and transition contexts. In System Innovation and the Transition to Sustainability: Theory, Evidence and Policy; Elzen, B., Geels, F.W., Green, K., Eds.; Edward Elgar: Cheltenham, UK, 2004; pp. 48-75.

20. Cordell, D.; Rosemarin, A.; Schröder, J.J.; Smit, A.L. Towards global phosphorus security: A systems framework for phosphorus recovery and reuse options. Chemosphere 2011, 84, 747-758. [CrossRef] [PubMed]

21. Cordell, D.; White, S. Peak Phosphorus: Clarifying the Key Issues of a Vigorous Debate about Long-Term Phosphorus Security. Sustainability 2011, 3, 2027-2049. [CrossRef]

22. Schröder, J.J.; Smit, A.L.; Cordell, D.; Rosemarin, A. Improved phosphorus use efficiency in agriculture: A key requirement for its sustainable use. Chemosphere 2011, 84, 822-831. [CrossRef] [PubMed]

23. Cordell, D.; Drangert, J.-O.; White, S. The story of phosphorus: Global food security and food for thought. Glob. Environ. Chang. 2009, 19, 292-305. [CrossRef]

24. European Commission. 20 critical raw materials-Major challenge for EU industry. Available online: http:/ / europa.eu/rapid/press-release_IP-14-599_en.htm (accessed on 3 July 2015).

25. Schoumans, O.F.; Bouraoui, F.; Kabbe, C.; Oenema, O.; van Dijk, K.C. Phosphorus management in Europe in a changing world. Ambio 2015, 44, 180-192. [CrossRef] [PubMed]

26. Galloway, J.; Burke, M.; Bradford, G.E.; Naylor, R.; Falcon, W.; Chapagain, A.K.; Gaskell, J.C.; McCullough, E.; Mooney, H.A.; Oleson, K.L.L.; et al. International trade in meat: The tip of the porkchop. Ambio 2007, 36, 622-629. [CrossRef]

27. Csatho, P.; Radimszky, L. Two worlds within EU27: Sharp contrasts in organic and mineral nitrogen-Phosphorus use, nitrogen-Phosphorus balances, and soil phosphorus status: Widening and deepening gap between Western and Central Europe. Commun. Soil Sci. Plant Anal. 2009, 40, 999-1019. [CrossRef]

28. Rubaek, G.H.; Kristensen, K.; Olesen, S.E.; Østergaard, H.S.; Heckrath, G. Phosphorus accumulation and spatial distribution in agricultural soils in Denmark. Geoderma 2013, 209-210, 241-250. [CrossRef]

29. White, S.; Cordell, D.; Moore, D. Securing a Sustainable Phosphorus Future for Australia: Implications of Global Phosphorus Scarcity and Possible Solutions; University of Technology: Sydney, Australia, 2010.

30. Schösler, H.; de Boer, J.; Boersema, J.J. Can we cut out the meat of the dish? Constructing consumer-oriented pathways towards meat substitution. Appetite 2012, 58, 39-47. [CrossRef] [PubMed]

31. Lundqvist, J.; de Fraiture, C.; Molden, D. Saving Water: From Field to Fork Curbing Losses and Wastage in the Food Chain. Available online: http://www.unwater.org/downloads/Paper_13_Field_to_Fork.pdf (accessed on 22 December 2015).

32. Papargyropoulou, E.; Lozano, R.; Steinberger, J.K.; Wright, N.; Bin Ujang, Z. The food waste hierarchy as a framework for the management of food surplus and food waste. J. Clean. Prod. 2014, 76, 106-115. [CrossRef] 
33. Cordell, D.; Neset, T.S.S.; Prior, T. The phosphorus mass balance: Identifying "hotspots" in the food system as a roadmap to phosphorus security. Curr. Opin. Biotech. 2012, 23, 839-845. [CrossRef] [PubMed]

34. Cordell, D.; Jackson, M.; White, S. Phosphorus flows through the Australian food system: Identifying intervention points as a roadmap to phosphorus security. Environ. Sci. Policy 2013, 29, 87-102. [CrossRef]

35. Pagotto, M.; Halog, A. Towards a Circular Economy in Australian Agri-food Industry An Application of Input-Output Oriented Approaches for Analyzing Resource Efficiency and Competitiveness Potential. J. Ind. Ecol. 2015. [CrossRef]

36. De Schutter, O. Report of the Special Rapporteur on the Right to Food, Final Report: The Transformative Potential of the Right to Food. Available online: http://www.srfood.org/images/stories/pdf/official reports/20140310_finalreport_en.pdf (accessed on 20 December 2015).

37. COM 2013. Report from the Commission to the European Parliament and the Council on the Case for a Local Farming and Direct Sales Labeling Scheme. Available online: http://ec.europa.eu/agriculture/quality/local -farming-direct-sales/pdf/com-report-12-2013_en.pdf (accessed on 24 February 2014).

38. Born, B.; Purcell, M. Avoiding the Local Trap: Scale and Food Systems in Planning Research. J. Plan. Educ. Res. 2006, 26, 195-207. [CrossRef]

39. De Boer, J.; Schösler, H.; Aiking, H. "Meatless days" or "less but better"? Exploring strategies to adapt Western meat consumption to health and sustainability challenges. Appetite 2014, 76, 120-128. [CrossRef] [PubMed]

40. Bere, E.; Brug, J. Towards health-promoting and environmentally friendly regional diets-A Nordic example. Public Health Nutr. 2008, 12, 91-96. [CrossRef] [PubMed]

41. Schösler, H.; de Boer, J.; Boersema, J.J.; Aiking, H. Meat and masculinity among young Chinese, Turkish and Dutch adults in the Netherlands. Appetite 2015, 89, 152-159. [CrossRef] [PubMed]

42. Ellen Mac Arthur Foundation. Growth within: A circular economy vision for a competitive Europe. 2015. Available online: http://www.ellenmacarthurfoundation.org/assets/downloads/publications/EllenMac ArthurFoundation_Growth-Within_July15.pdf (accessed on 20 August 2015).

(C) 2016 by the authors; licensee MDPI, Basel, Switzerland. This article is an open access article distributed under the terms and conditions of the Creative Commons by Attribution (CC-BY) license (http://creativecommons.org/licenses/by/4.0/). 